\title{
PROSES PRODUKSI METIL ESTER DARI MINYAK BIJI MAHONI DENGAN TRANSESTERIFIKASI IN SITU MENGGUNAKAN CO-SOLVENT THF (TETRAHYDROFURAN)
}

\author{
Elvianto Dwi Daryono*), Adrianus Chrisantus Rengga, dan Imaniar Safitri \\ Jurusan Teknik Kimia, Fakultas Teknologi Industri, Institut Teknologi Nasional Malang \\ Jl. Bendungan Sigura-gura No. 2 Malang, Indonesia \\ ${ }^{*}$ Penulis korespondensi: elviantodaryono@yahoo.com
}

\begin{abstract}
PRODUCTION OF PROCESS OF METHYL ESTER FROM MAHOGANY SEED OIL WITH IN SITU TRANSESTERIFICATION USING CO-SOLVENT THF (TETRAHYDROFURAN). The purpose of this research was to assess the effectiveness of the use of co-solvent THF for in situ transesterification reaction mahogany seed oil. Mahogany seeds which have been dried and pulverized size +20/-30 mesh around 50 grams. The pulverized seeds were inserted in to three-neck flask equipped with condenser. Methanol, THF and catalyst $\mathrm{NaOH}$ were added to the flask then the reaction was carried out with the certain variables and operating conditions. After the reaction was complete then the filtrate and cake were separated. To stop the reaction with neutralized the $\mathrm{NaOH}$ catalyst with added $\mathrm{HCl} 1 \mathrm{~mol} / \mathrm{L}$ to $\mathrm{pH}$ 4. The filtrate was distilled at a temperature of $70^{\circ} \mathrm{C}$ and the residue placed separating funnel and allowed for 12 hours in order to obtain two layers. The top layer as methyl ester was analyzed by GC as concentration of methyl ester. According to the result was obtained that the best results of this process achieved at a molar ratio of oil to THF of 1: 67.85 and reaction time of 23 minutes with methyl ester concentration of $69.28 \%$ and methyl ester yield of $67.95 \%$. Methyl ester density attained at $0.8791 \mathrm{~g} / \mathrm{cm}^{3}$ regards with SNI 04-7182-2006.
\end{abstract}

Keywords: biodiesel; co-solvent; in situ transesterification; mahogany seed oil

\begin{abstract}
Abstrak
Tujuan dari penelitian adalah untuk mengkaji efektifitas penggunaan co-solvent THF pada reaksi transesterifikasi in situ minyak biji mahoni. Biji mahoni yang telah dikeringkan dan dihaluskan ukuran +20/-30 mesh sebanyak 50 gram dimasukkan dalam labu leher tiga yang dilengkapi pendingin balik dan ditambahkan metanol, THF dan katalis $\mathrm{NaOH}$ serta dilakukan reaksi sesuai dengan variabel dan kondisi operasi penelitian. Setelah reaksi selesai dipisahkan antara ampas dan filtratnya. Untuk menghentikan reaksi yaitu menetralisasi katalis NaOH dengan menambahkan $\mathrm{HCl} 1$ mol/L sampai $p H$ 4. Filtrat didistilasi pada suhu $70^{\circ} \mathrm{C}$ dan residu hasil distilasi dimasukkan dalam corong pemisah dan didiamkan selama 12 jam agar terbentuk 2 lapisan. Lapisan atas sebagai metil ester kemudian dianalisis konsentrasi metil esternya dengan GC. Dari data hasil penelitian didapatkan hasil terbaik pada rasio molar minyak:THF = 1:67,85 dan waktu reaksi 23 menit dengan konsentrasi metil ester 69,28\% dan yield metil ester 67,95\%. Densitas metil ester 0,8791 $\mathrm{g} / \mathrm{cm}^{3}$ memenuhi SNI 04-7182-2006
\end{abstract}

Kata kunci: biodiesel; co-solvent; transesterifikasi in situ; minyak biji mahoni

How to Cite This Article: Daryono, E.D., Rengga, A.C., dan Safitri, I., (2014), Proses Produksi Metil Ester dari Minyak Biji Mahoni dengan Transesterifikasi In Situ Menggunakan co-solvent THF (Tetrahydrofuran), Reaktor, 15(1), 51-58, http://dx.doi.org/ 10.14710/reaktor.15.1.51-58

\section{PENDAHULUAN}

Energi terbarukan sangat dibutuhkan dewasa ini, terutama dalam hal kebutuhan energi bahan bakar. Bahan baku bahan bakar selama ini yang digunakan adalah bahan bakar fosil yang tidak dapat diperbaharui. Pasokan bahan baku yang semakin menipis inilah yang melatarbelakangi diadakan penelitian dan pengembangan untuk sumber-sumber 
energi terbarukan (renewable). Sumber energi terbarukan tersebut diharapkan dapat mengurangi penggunaan bakan bakar fosil dengan kebutuhan yang semakin meningkat. Salah satu kebutuhan bahan bakar yang semakin meningkat adalah bakan bakar solar. Kebutuhan solar Indonesia dari tahun ke tahun terus naik, pada tahun 1996-1997 sebesar 19,3 miliar liter, tahun 1997-1998 sebesar 22,2 miliar liter, tahun 19992000 impor BBM sebesar 31,707 miliar liter dan pada tahun 2007-2015 kebutuhan solar 19,3 miliar liter (Kompas 18 Maret 2002 dalam Susilo, 2006). Peningkatan ini akan terus terjadi setiap tahunnya seiring dengan pengembangan teknologi yang semakin maju dan jumlah penduduk yang semakin bertambah.

Pemerintah melalui Peraturan Presiden Republik Indonesia No. 5 Tahun 2006 tentang Kebijakan Energi Nasional, menetapkan pada tahun 2025 peran minyak bumi sebagai energi akan dikurangi dari 52\% saat ini menjadi kurang dari 20\%. Pada tahun tersebut diharapkan energi alternatif bisa menyuplai $17 \%$ kebutuhan energi nasional, termasuk di dalamnya biofuel atau Bahan Bakar Nabati (BBN) ikut memasok sekitar 5\% (Hambali dkk., 2007).

Biodiesel merupakan suatu energi alternatif yang telah dikembangkan secara luas untuk mengurangi ketergantungan terhadap Bahan Bakar Minyak (BBM). Biodiesel adalah metil ester asam lemak yang dihasilkan dari proses kimia antara minyak nabati dan alcohol. Produksi biodiesel dari minyak tumbuhan (seperti minyak kelapa sawit dan minyak jarak pagar) terkendala karena minyak kelapa sawit digunakan untuk minyak goreng. Pada umumnya biji dari varietas jarak pagar bersifat racun bagi manusia dan hewan karena adanya senyawa curcin dan phorbol esters (Kumar dan Sharma, 2008), serta perlu lahan luas untuk penanaman dan waktu yang relatif lama untuk pemanenan biji jarak pagar (Ariza-Montobbio dan Lele, 2010).

Salah satu alternatif bahan baku yang cukup menjanjikan adalah minyak biji mahoni. Biji mahoni selama ini belum termanfaatkan dan hanya sebagai limbah yang mengotori jalanan. Penanaman mahoni di Indonesia cukup luas, dimana pada umumnya penanaman mahoni yang luas dikelola oleh Perum Perhutani yang mengelola sekitar 116.282 ha di Jawa, Sumatera dan Sulawesi. Adapun sekitar belasan ribu hektar dikelola oleh Pemda sebagai tanaman peneduh jalan-jalan di banyak kota besar. Dengan luasan tersebut, selain berpotensi sebagai penghasil kayu, pohon reboisasi/penghijauan serta peneduh jalan dan dengan produksi biji mencapai $4-8 \mathrm{~kg} /$ pohon/tahun, biji mahoni dengan kandungan minyak yang cukup tinggi dapat dimanfaatkan untuk pembuatan biodiesel (Towaha, 2011).

Biji mahoni jenis Khaya Senegalensis mengandung minyak sekitar 52,5\%, tidak mengandung asam lemak esensial sehingga tidak mempunyai nilai nutrisi dan merupakan minyak non pangan (Eromosele dkk., 1998; Okieimen dkk., 1999). Kandungan minyak biji mahoni lebih besar dari kandungan minyak biji jarak pagar yang sekitar 3050\% (Ong dkk., 2011). Komposisi asam lemak pada minyak biji mahoni adalah asam stearat $(10,41 \%)$, asam palmitat $(21,39 \%)$, asam oleat $(64,62 \%)$ dan asam-asam lain (3,58\%) (Okieimen dkk., 1999).

Beberapa penelitian tentang pembuatan biodiesel dari minyak biji mahoni telah dilakukan. Pada transesterifikasi neem oil didapatkan yield $83 \%$ pada suhu reaksi $50^{\circ} \mathrm{C}$, waktu reaksi 90 menit, katalis $\mathrm{NaOH}$ 1,5\% berat dan volume metanol $180 \mathrm{~mL}$ (Eevera dkk., 2009). Aliyu dkk., (2012) melakukan transesterifikasi minyak biji mahoni sebanyak $15 \mathrm{~cm}^{3}$ dengan katalis $\mathrm{NaOH}$ pelet 0,1648 gram dan metanol $42 \mathrm{~cm}^{3}$ pada suhu $60^{\circ} \mathrm{C}$ dan waktu reaksi 30 menit. Mereka menghasilkan biodiesel yang memenuhi ASTM D 6751-06 standard sebagai biodiesel (B100). Radha dan Manikandan (2011) melakukan transesterifikasi minyak biji Neem (Azadirachta indica) yaitu pohon mahoni keluarga Meliaceae yang tumbuh di India dengan katalis $\mathrm{NaOH}$. Mereka mendapatkan metil ester dengan yield $83 \%$ pada suhu reaksi $55^{\circ} \mathrm{C}$, rasio mol minyak:metanol $=1: 12$ dan waktu reaksi 2 jam. Damayanti dan Bariroh (2012), melakukan transesterifikasi minyak biji mahoni dan mendapatkan yield metil ester $86,92 \%$ pada rasio mol minyak:metanol $=1: 6$, katalis $\mathrm{KOH} 0,1 \mathrm{~N}$, suhu reaksi $60^{\circ} \mathrm{C}$ dan waktu reaksi 1 jam. Biodiesel yang dihasilkan memenuhi SNI-04-7182-2006 (densitas $874,08 \mathrm{~kg} / \mathrm{m}^{3}$, viskositas $3,07 \mathrm{~mm}^{2} / \mathrm{s}$ dan bilangan asam $0,5601 \mathrm{mg} \mathrm{KOH} / \mathrm{gr}$ ).

Secara umum pengolahan biodiesel (metil ester) dilakukan dengan proses konvensional. Proses konvensional untuk memproduksi biodiesel/FAME melibatkan ekstraksi minyak, pemurnian dan transesterifikasi (Haas dkk., 2004). Jika bahan baku biodiesel minyak dari biji, akan membebani 70\% dari total biaya produksi biodiesel (Bender, 1999 ; Haas dkk., 2006).

Transesterifikasi in situ dapat menjadi salah satu alternatif untuk mendapatkan proses yang lebih efisien. Proses transesterifikasi in situ merupakan salah satu unit operasi terintegrasi yang terdiri dari ekstraktor (sebagai tempat terjadinya proses ekstraksi) dan reaktor (sebagai tempat terjadinya reaksi) yang berada dalam unit peralatan. Dalam proses transesterifikasi in situ, ekstraksi minyak serta esterifikasi dan/atau transesterifikasi dilakukan dalam satu langkah dimana alkohol berfungsi sebagai pelarut ekstraksi sekaligus sebagai reagen transesterifikasi selama proses transesterifikasi in situ berlangsung (Supardan dkk., 2014).

Pada transesterifikasi in situ yang menjadi masalah adalah kelarutan minyak dalam metanol rendah sehingga akan membentuk reaksi dua fase, sedangkan katalis berada di fase metanol dan reaksi terjadi pada fase tersebut. Dengan menambahkan pelarut yaitu Co-solvent, akan meningkatkan kelarutan minyak pada metanol sehingga akan membentuk reaksi satu fase (Boocock dkk., 1996). 
Zeng dkk., (2009) melakukan reaksi transesterifikasi in situ minyak biji bunga matahari menggunakan metanol dengan penambahan co-solvent DEM (Diethoxymethane). Mereka mendapatkan produk dengan 97,7\% FAME dan 0,74\% FFA pada rasio molar katalis:minyak $=0,5: 1$, rasio molar metanol:minyak = 101,39:1, rasio molar DEM:minyak $=57,85: 1$, kecepatan pengaduk $150 \mathrm{rpm}$, suhu reaksi $20^{\circ} \mathrm{C}$ dan waktu reaksi 13 menit. Shuit dkk., (2010) mendapatkan FAME dengan yield 99,8\% dengan ukuran biji jarak pagar $<0,355 \mathrm{~mm}$, co-solvent $\mathrm{n}$ heksan $10 \%$ vol. metanol, suhu reaksi $60^{\circ} \mathrm{C}$, waktu reaksi 24 jam, rasio metanol: biji yaitu $7,5 \mathrm{ml} / \mathrm{gr}$ dan katalis $\mathrm{H}_{2} \mathrm{SO}_{4}$ 15\%. Supardan dkk (2014) melakukan transesterifikasi in situ biji jarak pagar menggunakan kavitasi hidrodinamik. Mereka mendapatkan biodiesel dengan yield $60 \%$ pada rasio volume methanol:biji 16 $\mathrm{ml} / \mathrm{gr}$, volume metanol $800 \mathrm{ml}$, suhu reaksi $50^{\circ} \mathrm{C}$, waktu reaksi 120 menit, katalis $\mathrm{KOH} 2$ gr, kandungan air biji, 3\%, ukuran biji 0,355-1,18 mm dan volume co-solvent n-heksan $95 \mathrm{ml}$. Kartika dkk. (2012) mendapatkan biodiesel dengan yield $89 \%$ pada rasio metanol:biji jarak pagar $6: 1,0,075 \mathrm{~mol} / \mathrm{L} \mathrm{KOH}$ dalam metanol, rasio n-heksan:metanol:bahan 3:3:1, kecepatan pengadukan $600 \mathrm{rpm}$, suhu reaksi $40^{\circ} \mathrm{C}$ dan waktu reaksi 6 jam. Boey dkk., (2011) melakukan transesterifikasi in situ CPO yang teradsorbsi pada SBC (Spent Bleaching Clay) dengan proses ultrasonik. Mereka mendapatkan yield metil ester $75,2 \%$ pada rasio mol metanol: minyak 150:1, massa SBC 2 gram, katalis $\mathrm{KOH} 20 \%$, suhu reaksi $60^{\circ} \mathrm{C}$, waktu reaksi 2 jam dan co-solvent petroleum eter $3 \mathrm{ml}$. Hincapie dkk., (2011) mendapatkan yield metil ester 65,6\% pada waktu reaksi 2 jam, kecepatan pengadukan 300

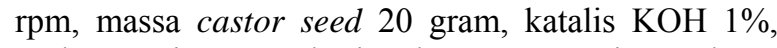
molar rasio etanol:minyak 60:1, rasio volume etanol:n-heksan $=20 \%$ dari volume minyak. Khang dkk., (2014) melakukan transesterifikasi in situ kopra dengan menggunakan campuran metanol dan THF. Mereka mendapatkan yield tertinggi $96,7 \%$ pada suhu reaksi $60^{\circ} \mathrm{C}$, waktu reaksi $20 \mathrm{jam}$, rasio metanol/kopra $=200 \mathrm{~mL} / 100 \mathrm{~g}$, rasio volume THF:metanol $=0,4$, rasio molar metanol:minyak $=60: 1$ dan katalis $\mathrm{H}_{2} \mathrm{SO}_{4}$ sebanyak $15 \mathrm{~mL}$. Pada transesterifikasi in situ minyak biji pepaya dengan co-solvent THF, didapatkan yield $84,7685 \%$ pada waktu reaksi 23 menit dan rasio molar THF:minyak = 1:67,85 (Daryono dkk., 2014).

Penelitian ini bertujuan untuk mencari kondisi proses yang lebih baik dan hemat energi yaitu reaksi pada suhu kamar, waktu reaksi dalam pembentukan metil ester yang lebih cepat dan rasio molar minyak: co-solvent yang optimum dibandingkan dengan proses transesterifikasi konvensional.

\section{METODE PENELITIAN}

Bahan penelitian utama yaitu biji mahoni yang didapatkan dari daerah Blitar. Reagen yang digunakan dalam penelitian meliputi metanol (MERCK, 99,9\%), THF (MERCK, 99,8\%) dan $\mathrm{NaOH}$ pellet (Riedel-de Haen, 99\%). Reaksi dilakukan pada skala laboratorium menggunakan labu alas bulat berleher tiga dilengkapi pendingin balik, termometer dan pengaduk magnetik. Suhu reaksi dijaga pada suhu kamar $\left( \pm 27^{\circ} \mathrm{C}\right)$ menggunakan penangas air dan tekanan atmosferik. Pemilihan suhu kamar dilakukan untuk menghemat energi dan membandingkan dengan hasil penelitian Zeng dkk., (2009), yang mendapatkan kondisi optimum pada suhu $20^{\circ} \mathrm{C}$.

Biji mahoni yang telah dikeringkan dan dihaluskan ukuran $+20 /-30$ mesh, dianalisa kadar airnya dan \%FFA-nya. Merangkai reaktor sebagai tempat reaksi yang terdiri dari labu leher tiga dan pendingin balik serta memperkuat posisinya dengan penyangga dan statif. Kemudian meletakkan reaktor pada hot plate magnetic stirrer. Memasukkan 50 gram biji mahoni kering, metanol, THF dan $\mathrm{NaOH}$ ke dalam reaktor dan melakukan reaksi pada suhu kamar $( \pm$ $27^{\circ} \mathrm{C}$ ) serta mengatur tombol putaran magnetic stirrer pada kecepatan $150 \mathrm{rpm}$. Pengontrolan suhu reaksi dilakukan dengan melihat suhu termometer yang dipasang pada reaktor dan penguapan metanol serta THF dicegah dengan pendingin balik. Pemilihan kecepatan $150 \mathrm{rpm}$ didasari oleh kondisi optimum yang didapatkan Zeng dkk., (2009). Digunakan katalis $\mathrm{NaOH}$ pellet dengan rasio molar minyak: $\mathrm{NaOH}=$ $1: 0,5$, rasio molar minyak:metanol $=1: 101,39$, dan rasio molar minyak:THF $=1: 47,15 ; 1: 57,85$ dan 1:67,85 (Zeng dkk., 2009). Rasio molar minyak:metanol pada penelitian ini cukup tinggi karena fungsi metanol selain sebagai reaktan juga pelarut untuk mengekstraksi minyak pada biji.

Sampel sebagai hasil reaksi diambil sebanyak 10 gram pada masing-masing waktu reaksi $(3,8,13$, 18, dan 23 menit). Untuk menghentikan reaksi yaitu menetralkan katalis $\mathrm{NaOH}$ dengan menambahkan $\mathrm{HCl}$ $1 \mathrm{~mol} / \mathrm{L}$ sampai $\mathrm{pH} 4$ pada hasil reaksi (Zeng dkk., 2009). Hasil reaksi dan ampas biji mahoni kemudian dipisahkan dengan kertas saring. Hasil reaksi kemudian di-distilasi pada suhu $70^{\circ} \mathrm{C}$ sampai tidak ada destilat yang menetes. Pemisahan sisa metanol dan $\mathrm{CO}^{-}$ solvent THF dapat dilakukan dengan mudah karena titik didihnya yang berdekatan (Boocock dkk., 1996). Destilat merupakan metanol dan co-solvent sisa, sedangkan residu merupakan campuran dari metil ester, minyak, gliserol dan katalis. Residu dimasukkan dalam corong pemisah selama 12 jam sampai terbentuk 2 lapisan kemudian dipisahkan. Lapisan bawah yang berwarna kecoklatan adalah gliserol dan katalis $\mathrm{NaOH}$, sedangkan lapisan atas yang berwarna kuning adalah metil ester dan minyak biji mahoni yang tidak bereaksi. Lapisan atas ditimbang sebagai berat metil ester. Lapisan atas kemudian dianalisa konsentrasi metil esternya dengan menggunakan GC merk Shimadzu dengan data :

- Column : BPX5 0,25 $\mu \mathrm{m}, 12 \mathrm{~m}$ x 0,53 mm ID

- Initial temp : $100^{\circ} \mathrm{C}, 0,5 \mathrm{~min}$

- Rate $1: 50^{\circ} \mathrm{C} / \mathrm{min}$

- Temp $: 280^{\circ} \mathrm{C}$

- Rate $2 \quad: 10^{\circ} \mathrm{C} / \mathrm{min}$

- Final temp : $360^{\circ} \mathrm{C}, 5 \mathrm{~min}$ 
- Carrier gas : He, 5 min

- Detektor : FID

- Injection mode : on column (OCI-5)

- Injection volume : $1 \mu 1$

\section{Diskripsi Peralatan}

Pada penelitian ini sebagai reaktor digunakan labu leher tiga yang dilengkapi dengan pendingin balik (Gambar 1). Kecepatan pengadukan magnetic stirrer diatur dengan memakai putaran skala pada hot plate. Penelitian menggunakan suhu reaksi pada suhu kamar, sehingga tidak mengfungsikan pengatur suhu.

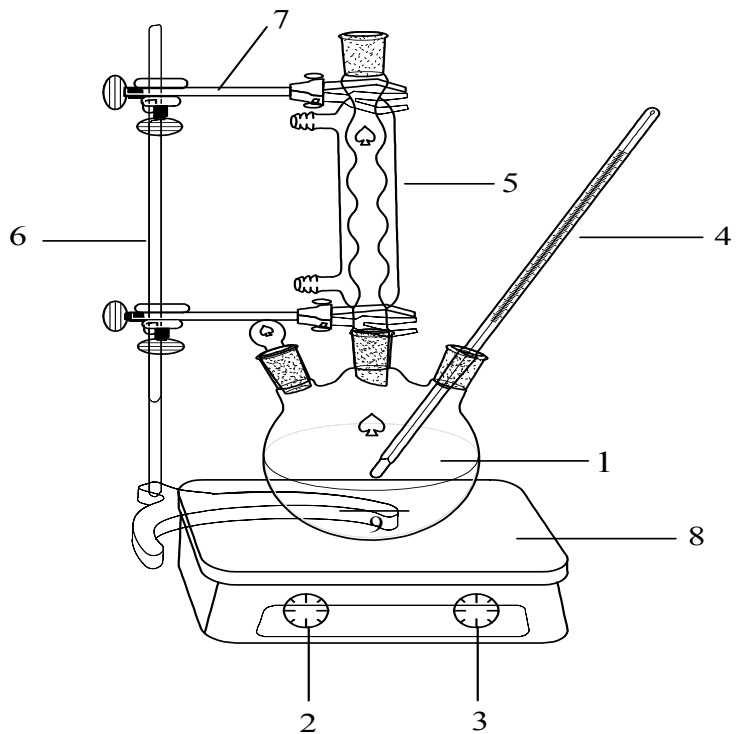

Gambar 1. Reaktor Transesterifikasi In Situ

Keterangan:

1. Labu leher tiga

2. Tombol pengatur temperatur

3. Tombol pengatur kecepatan stirrer

4. Termometer

5. Pendingin balik

6. Penyangga

7. Statif

8. Hot plate

9. Magnetic Stirer

\section{HASIL DAN PEMBAHASAN}

Bahan baku yaitu biji mahoni setelah dikeringkan dan dihaluskan, dianalisa kadar airnya dan didapatkan kadar air 0,8\%. Biji mahoni serbuk kemudian diekstraksi minyaknya dengan pelarut metanol dan THF dengan rasio molar metanol:THF 101,39:67,85 selama 23 menit. Dari hasil ekstraksi didapatkan 28 gram minyak pada 50 gram biji mahoni kering. Minyak hasil ekstraksi dianalisa \%FFA-nya dan didapatkan \%FFA $1,42 \%$, sehingga dapat langsung dilakukan reaksi transesterifikasi in situ.

Data konsentrasi metil ester didapatkan dari hasil analisa GC lapisan atas residu hasil pemisahan dengan distilasi. Dari hasil analisa GC komponen metil ester terdiri dari metil oleat, metil heksanoat, metil oktanoat, metil miristat, metil palmitat, metil heptadekanoat, metil linoleat, metil stearat, metil laurat dan metil arakidat.

Yield metil ester dihitung dengan menggunakan persamaan berikut :

Yield $(\%)=\frac{(\Sigma \text { Konsentrasi metil ester }) x(\text { Berat metil ester })}{(\text { Berat minyak biji mahoni mula-mula })} \times 100 \%$

Minyak biji mahoni yang didapatkan dari hasil ekstraksi dengan pelarut, kemudian dianalisa komposisi asam lemaknya dengan GC (Tabel 1).

Tabel 1. Komposisi asam lemak pada minyak biji mahoni hasil analisa GC

\begin{tabular}{cc}
\hline Asam lemak & \% berat \\
\hline Asam oktanoat & 1,24 \\
Asam heksanoat & 0,17 \\
Asam hekpadekanoat & 2,606 \\
Asam laurat & 2,906 \\
Asam miristat & 7,397 \\
Asam palmitat & 9,096 \\
Asam stearat & 7,411 \\
Asam oleat & 36,147 \\
Asam linoleat & 9,952 \\
Asam arakidat & 9,401 \\
\hline
\end{tabular}

\section{Pengaruh Rasio Molar THF:Minyak dan Waktu Reaksi terhadap Berat Metil Ester}

Residu hasil distilasi setelah dipisahkan kemudian ditimbang berat metil esternya. Penimbangan dilakukan untuk tiap variabel rasio molar THF:minyak pada berbagai waktu reaksi. Dari Tabel 2 dapat dilihat bahwa rasio molar THF:minyak dan waktu reaksi memberikan pengaruh yang nyata pada berat metil ester yang didapatkan. Semakin besar rasio molar THF:minyak dan semakin lama waktu reaksi, menghasilkan berat metil ester yang semakin tinggi.

Tabel 2. Berat metil ester pada berbagai variabel rasio molar THF:minyak dan waktu reaksi

\begin{tabular}{ccc}
\hline $\begin{array}{c}\text { Rasio molar } \\
\text { THF:minyak }\end{array}$ & $\begin{array}{c}\text { Waktu reaksi } \\
\text { (menit) }\end{array}$ & $\begin{array}{c}\text { Berat metil ester } \\
\text { (gram) }\end{array}$ \\
\hline & 3 & 0,189 \\
$47,15: 1$ & 8 & 0,243 \\
& 13 & 0,405 \\
& 18 & 0,432 \\
& 23 & 0,567 \\
$57,85: 1$ & 3 & 0,27 \\
& 13 & 0,243 \\
& 18 & 0,351 \\
& 23 & 0,378 \\
& 3 & 0,621 \\
& 8 & 0,324 \\
$67,85: 1$ & 13 & 0,378 \\
& 18 & 0,459 \\
& 23 & 0,567 \\
& & 0,891 \\
\hline
\end{tabular}

Pada waktu reaksi 23 menit dengan rasio molar THF:minyak 47,15:1 didapatkan berat metil ester 0,567 gram, pada rasio molar THF:minyak 57,85:1 didapatkan berat metil ester 0,621 gram dan pada rasio 
molar THF:minyak 67,85:1 didapatkan berat metil ester 0,891 gram. Pada rasio molar THF:minyak 47,15:1 dan 57,85:1, berat metil ester yang didapatkan tidak berbeda jauh hanya selisih 0,054 gram. Tetapi pada rasio molar THF:minyak 57,85:1 dan 67,85:1, berat metil ester yang didapatkan berbeda cukup jauh yaitu selisih 0,27 gram. Dari hasil tersebut dapat dikatakan bahwa rasio molar THF:minyak merupakan variabel yang paling berpengaruh pada peningkatan berat metil ester. Untuk semua variabel rasio molar THF:minyak, peningkatan berat metil ester yang tertinggi terjadi pada waktu reaksi 18 menit menuju ke 23 menit. Dari variabel waktu reaksi belum didapatkan data berat metil ester optimum, karena berat metil ester masih mengalami kenaikan. Hasil terbaik didapatkan pada ratio molar minyak:THF adalah 1:67,85 dan waktu reaksi 23 menit dengan berat metil ester 0,891 gram.

\section{Pengaruh Rasio Molar THF:Minyak terhadap \%FFA dan Densitas Biodiesel}

Ratio molar THF:minyak berpengaruh pada $\%$ FFA dan densitas biodiesel yang dihasilkan. Analisa $\%$ FFA dan densitas biodiesel dilakukan pada variabel rasio molar THF:minyak untuk waktu reaksi 23 menit. Dari Tabel 3 terlihat bahwa semakin tinggi ratio molar THF:minyak, maka semakin kecil \% FFA metil ester. Hal ini karena dengan semakin banyaknya minyak yang bereaksi menjadi metil ester, maka semakin sedikit sisa minyak yang tidak bereaksi yang merupakan sumber penyebab tingginya FFA. Semakin kecil \%FFA maka semakin baik kualitas metil ester yang dihasilkan, karena \%FFA berhubungan dengan kerusakan komponen penyusun metil ester. Hasil terbaik \%FFA didapatkan pada ratio molar THF:minyak 67,85:1 yaitu 0,5004\%. Zeng dkk.,2006 mendapatkan metil ester dari biji bunga matahari dengan \%FFA $0,74 \%$ pada transesterifikasi in situ dengan rasio molar DEM:minyak 57,85:1.

Semua densitas metil ester yang dihasilkan memenuhi spesifikasi SNI 04-7182-2006 yaitu 0,85 $0,89 \mathrm{~g} / \mathrm{cm}^{3}$. Pada rasio molar THF:minyak 1:67,85 yang merupakan kondisi terbaik didapatkan densitas metil ester $0,8791 \mathrm{~g} / \mathrm{cm}^{3}$.

Tabel 3. Pengaruh ratio molar THF:minyak terhadap $\%$ FFA dan densitas metil ester

\begin{tabular}{ccc}
\hline $\begin{array}{c}\text { Ratio molar } \\
\text { THF:minyak }\end{array}$ & \%FFA & Densitas $\left(\mathrm{g} / \mathrm{cm}^{3}\right)$ \\
\hline $47,15: 1$ & 0,5488 & 0,8569 \\
$57,85: 1$ & 0,5326 & 0,8751 \\
$67,85: 1$ & 0,5004 & 0,8791 \\
\hline
\end{tabular}

\section{Pengaruh Rasio Molar THF:Minyak dan Waktu Reaksi terhadap Konsentrasi Metil Ester}

Rasio molar THF:minyak dan waktu reaksi sangat berpengaruh terhadap konsentrasi metil ester yang dihasilkan. Berdasarkan Gambar 2 dapat dilihat bahwa penambahan co-solvent THF mengakibatkan reaksi transesterifikasi in situ berjalan cukup cepat di awal reaksi. Tercapai konsentrasi metil ester sekitar 20\% pada waktu reaksi 3 menit. Pada transesterifikasi in situ minyak biji pepaya tanpa co-solvent, didapatkan konsentrasi metil ester $43,02 \%$ pada waktu reaksi 30 menit dengan volume metanol $400 \mathrm{~mL}$ (Daryono, 2013). Penambahan co-solvent THF kurang berpengaruh pada perolehan konsentrasi metil ester dibandingkan dengan variabel waktu reaksi.

Terlihat dari Gambar 2, kondisi terbaik pada rasio molar THF:minyak 57,85:1 dengan waktu reaksi 23 menit didapatkan konsentrasi metil ester $60,52 \%$, sedangkan pada rasio molar THF:minyak 67,85:1 dengan waktu reaksi 23 menit didapatkan konsentrasi metil ester 69,28\% hanya selisih 8,76\%. Daryono, (2013) mendapatkan konsentrasi metil ester 56,71\% pada transesterifikasi in situ minyak biji pepaya tanpa co-solvent pada waktu reaksi 150 menit dengan volume metanol $400 \mathrm{~mL}$. Dengan semakin tingginya rasio molar penambahan THF dan semakin lama waktu reaksi, akan didapatkan konsentrasi metil ester yang semakin meningkat. Hal ini disebabkan karena dengan semakin lama waktu reaksi maka semakin banyak FAME yang didapatkan, karena semakin lama solvent dan co-solvent mengekstrak minyak dari biji mahoni, maka minyak yang dihasilkan semakin banyak dalam proses transesterifikasi in situ. Penambahan THF selain sebagai co-solvent untuk mempercepat reaksi juga membantu mengekstrak minyak dari biji mahoni. Semakin banyak menambahkan THF dapat meningkatkan kelarutan minyak terhadap metanol dan reaksi berjalan semakin cepat karena membentuk sistem satu fase dan menghasilkan metil ester yang semakin banyak.

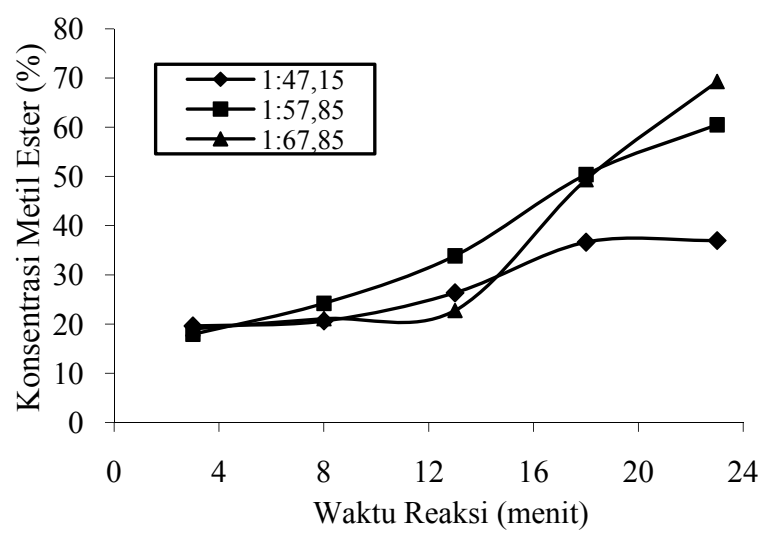

Gambar 2. Pengaruh waktu reaksi (menit) dan rasio molar minyak:Co-solvent terhadap konsentrasi metil ester (\%) hasil reaksi transesterifikasi in situ minyak biji mahoni

\section{Pengaruh Rasio Molar THF:Minyak dan Waktu Reaksi terhadap Yield Metil Ester}

Rasio molar THF:minyak dan waktu reaksi sangat berpengaruh terhadap yield metil ester yang dihasilkan. Dari Gambar 3 dapat dilihat bahwa dengan semakin tingginya rasio molar penambahan THF dan semakin lama waktu reaksi, akan didapatkan yield 
metil ester yang semakin tinggi. Hal ini disebabkan karena dengan semakin lama waktu reaksi maka semakin banyak metil ester yang didapatkan. Semakin lama solvent dan co-solvent mengekstrak minyak biji mahoni, maka akan menghasilkan minyak semakin banyak yang merupakan reaktan dalam membentuk metil ester dalam proses transesterifikasi in situ. Dapat terlihat juga bahwa penambahan co-solvent THF dapat meningkatkan metil ester yang dihasilkan. Hal ini disebabkan karena THF selain sebagai co-solvent untuk mempercepat reaksi juga membantu mengekstrak minyak dari biji mahoni. Semakin banyak THF yang ditambahkan, kelarutan TG terhadap metanol semakin besar dan reaksi berjalan semakin cepat dan metil ester yang dihasilkan semakin banyak.

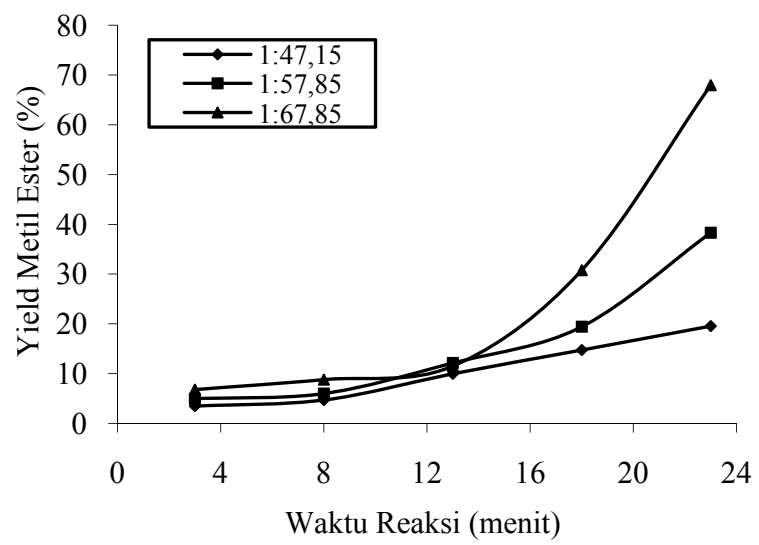

Gambar 3. Pengaruh waktu reaksi (menit) dan rasio molar minyak:co-solvent terhadap yield metil ester (\%) hasil reaksi transesterifikasi in situ minyak biji mahoni

Reaksi berjalan cukup lambat di awal reaksi yaitu di waktu reaksi 3, 8 dan 13 menit. Tetapi pada waktu reaksi 18 dan 23 menit reaksi berjalan cepat. Penambahan co-solvent THF dan waktu reaksi sangat berpengaruh pada perolehan yield metil ester. Terlihat dari Gambar 3, kondisi terbaik pada rasio molar THF:minyak 57,85:1 dengan waktu reaksi 23 menit didapatkan yield metil ester $38,31 \%$, sedangkan pada rasio molar THF:minyak 67,85:1 dengan waktu reaksi 23 menit didapatkan yield metil ester $67,95 \%$ dan ini merupakan kondisi terbaik pada penelitian ini. Transesterifikasi neem oil mendapatkan yield $83 \%$ pada suhu reaksi $50^{\circ} \mathrm{C}$, waktu reaksi 90 menit, katalis $\mathrm{NaOH} 1,5 \%$ berat dan volume metanol $180 \mathrm{~mL}$ (Eevera dkk., 2009). Pada transesterifikasi konvensional minyak biji Neem (Azadirachta indica) tanpa co-solvent didapatkan yield $83 \%$ pada suhu reaksi $55^{\circ} \mathrm{C}$, rasio mol minyak:metanol $=1: 12$ dan waktu reaksi 2 jam (Radha dan Manikandan, 2011). Transesterifikasi minyak biji mahoni mendapatkan yield metil ester $86,92 \%$ pada rasio mol minyak:metanol $=1: 6$, suhu reaksi $60^{\circ} \mathrm{C}$ dan waktu reaksi 1 jam (Damayanti dan Bariroh, 2012).
Jika dibandingkan dengan hasil ketiga penelitian transesterifikasi minyak biji mahoni diatas, maka hasil penelitian ini relatif lebih baik karena yield metil ester tertinggi $67,95 \%$ didapatkan pada waktu reaksi 23 menit dengan reaksi pada suhu kamar. Pada transesterifikasi konvensional rasio mol minyak:metanol yang digunakan lebih kecil jika dibandingkan dengan rasio mol minyak:metanol pada transesterifikasi in situ dengan co-solvent. Hal ini karena metanol sebagai solvent pada transesterifikasi in situ selain sebagai reaktan/membantu reaksi, juga untuk mengekstrak minyak dari biji berbeda dengan transesterifikasi konvensional yang minyaknya sudah tersedia sebagai reaktan.

Zeng dkk. (2009) mendapatkan yield metil ester tertinggi $97,7 \%$ pada waktu reaksi 13 menit, rasio molar minyak: $\mathrm{THF}=1: 57,85$ dengan bahan baku biji bunga matahari dan co-solvent DEM (diethoxymethane). Perbedaan ini disebabkan karena kelarutan DEM terhadap metanol dan minyak lebih tinggi dibanding THF (laju ekstraksi minyak pada DEM 95,85\% dan pada THF 92,87\%) (Zeng dkk., 2009). Shuit dkk. (2010) mendapatkan yield metil ester $\pm 10 \%$ pada waktu reaksi 1 jam untuk transesterifikasi in situ biji jarak pagar dengan co- $^{-}$ solvent $\mathrm{n}$-heksan. Mereka mendapatkan yield tertinggi $99,8 \%$ dengan co-solvent n-heksan $10 \%$ vol. metanol, suhu reaksi $60^{\circ} \mathrm{C}$, waktu reaksi 24 jam dan rasio metanol: biji $7,5 \mathrm{ml} / \mathrm{gr}$. Penelitian Supardan $\mathrm{dkk}$ (2014) yaitu transesterifikasi in situ biji jarak pagar dengan co-solvent n-heksan menggunakan kavitasi hidrodinamik, mendapatkan yield biodiesel $60 \%$ pada suhu reaksi $50^{\circ} \mathrm{C}$, rasio volume methanol:biji $16 \mathrm{ml} / \mathrm{gr}$, volume metanol 800 mlvolume co-solvent n-heksan $95 \mathrm{ml}$, dan waktu reaksi 120 menit. Kartika dkk. (2012) mendapatkan yield biodiesel $89 \%$ pada rasio metanol:biji jarak pagar 6:1, rasio nheksan:metanol:bahan $3: 3: 1$, kecepatan pengadukan $600 \mathrm{rpm}$, suhu reaksi $40^{\circ} \mathrm{C}$ dan waktu reaksi 6 jam. Hasil penelitian ini relatif lebih baik karena yield metil ester tertinggi adalah $67,95 \%$ didapatkan pada waktu reaksi 23 menit, suhu reaksi pada suhu kamar, kecepatan pengadukan $150 \mathrm{rpm}$ dan menggunakan $\mathrm{co}^{-}$ solvent THF.

Hincapie dkk. (2011) mendapatkan yield metil ester $65,6 \%$ pada waktu reaksi 2 jam, rasio volume etanol:n-heksan $=20 \%$ dari volume minyak. Khang dkk., (2014) mendapatkan yield tertinggi 96,7\% pada suhu reaksi $60^{\circ} \mathrm{C}$, waktu reaksi 20 jam, rasio metanol $/$ kopra $=200 \mathrm{~mL} / 100 \mathrm{~g}$, rasio volume THF:metanol $=0,4$ dan katalis $\mathrm{H}_{2} \mathrm{SO}_{4}$ sebanyak 15 $\mathrm{mL}$. Hasil penelitian ini lebih baik, dimana yield metil ester tertinggi 67,95\% didapatkan pada reaksi dengan suhu kamar, waktu reaksi 23 menit dan menggunakan katalis $\mathrm{NaOH}$. Pada transesterifikasi in situ minyak biji pepaya dengan co-solvent THF, didapatkan yield $84,7685 \%$ pada waktu reaksi 23 menit dan rasio molar THF:minyak adalah 1:67,85 (Daryono dkk., 2014). Hasil penelitian ini berbeda, karena pada penelitian Daryono dkk., 2014 perhitungan yield tidak 
memperhitungkan konsentrasi metil ester yang didapatkan.

\section{KESIMPULAN}

Konsentrasi metil ester tertinggi 69,28\% dan yield metil ester tertinggi $67,95 \%$ didapatkan pada waktu reaksi 23 menit, suhu reaksi $27^{\circ} \mathrm{C}$, rasio molar minyak: $\mathrm{NaOH}$ adalah 1:0,5, rasio molar minyak:metanol adalah 1:101,39, dan rasio molar minyak:THF adalah 1:67,85. Hal ini karena semakin lama waktu reaksi dan semakin besar rasio molar minyak:co-solvent maka konsentrasi metil ester dan yield metil ester semakin besar. Yield metil ester yang dihasilkan pada transesterifikasi in situ minyak biji mahoni dengan co-solvent jauh lebih tinggi jika dibandingkan dengan proses transesterifikasi minyak biji mahoni konvensional dengan waktu reaksi yang sama. Dari perbandingan dengan penelitian terdahulu diketahui bahwa co-solvent THF berperan lebih baik dalam pembentukan metil ester dibanding co-solvent n-heksan. Hal ini karena THF bisa berperan sebagai pelarut yang bersifat polar (bisa melarutkan metanol) dan juga bisa bersifat non polar (bisa melarutkan minyak), dibanding n-heksan yang hanya bersifat non polar. Penggunaan katalis basa akan menghasilkan yield metil ester yang lebih tinggi dalam waktu yang relatif singkat dibandingkan dengan katalis asam.

\section{DAFTAR PUSTAKA}

Aliyu, A., Lomsahaka, E., and Hamza, A., (2012), Production of biodiesel via $\mathrm{NaOH}$ catalyzed transesterification of mahogany seed oil, Adv. Appl. Sci. Res., 3, pp. 615-618.

Ariza-Montobbio, P. and Lele, S., (2010), Jatropha plantations for biodiesel in Tamil Nadu, India : viability, livelihood trade-offs, and latent conflict, Ecological Economic, 70, pp. 189-195.

Bender, M., (1999), Economic Feasibility Review for Community-Scale Farmer Cooperatives for Biodiesel, Bioresour. Technol., 70, pp. 81-87.

Boocock, D.G.B., Konar, S.K., Mao, V., and Sidi, H., (1996), Fast One-Phase Oil-Rich Process for The Preparation of Vegetable Oil Methyl Esters, Biomass Bioenergy, 11, pp. 43-50.

Boey, P.L., Ganesan, S., Maniam, G.P., and Ali, D.M.H., (2011), Ultrasound Aided In Situ Transesterification of Crude Oil Adsorbed on Spent Bleaching Clay, Energy Conversion and Management, 52, pp. 2081-2084.

Damayanti, A. dan Bariroh, S., (2012), Pengolahan Biji Mahoni (Swietenia Macrophylla King) Sebagai Bahan Baku Alternatif Biodiesel, Jurnal Bahan Alam Terbarukan, 1 (1), hal. 8-15.
Daryono, E.D., (2013), Biodiesel dari Minyak Biji Pepaya dengan Transesterifikasi Insitu, Jurnal Teknik Kimia, UPN Veteran Surabaya, 8(1), hal. 7-11.

Daryono, E.D., Hudha, M.I., dan Muyassaroh, (2014), Sintesa Biodiesel dari Minyak Biji Pepaya dengan Reaksi Transesterifikasi In Situ Menggunakan Cosolvent THF (Tetrahydrofuran), Prosiding Seminar Nasional Kimia, Jurusan Kimia FMIPA Unesa, pp. B292-B-300.

Eromosele, I.C., Eromosele, C.O., Innazo, P., and Njerim, P., (1998), Studies on Some Seeds and Seed Oils, Bioresource Technology, 64, pp. 245-247.

Eevera, T., Rajendran, K., and Saradha, S., (2009), Biodiesel production process optimization and characterization to assess the suitability of the product for varied environmental conditions, Renewable Energy, 34, pp. 762-765.

Haas, M.J., Scott, K.M., Marmer, W.N., and Foglia, T.A., (2004), In Situ Alkaline Transesterification: an Effective Method for The Production of Fatty Acid Esters from Vegetable Oils, Journal of American Oil Chemists' Society, 81, pp. 83-89.

Haas, M.J., McAloon, A.J., Yee, W.C., and Foglia, T.A., (2006), A Process Model to Estimate Biodiesel Production Costs, Bioresour. Technol., 97, pp. 671678.

Hincapie, G., Mondragon, F., and Lopez, D., (2011), Conventional and In Situ Transesterification of Castor Seed Oil for Biodiesel Production, Fuel, 90, pp. 16181623.

Kartika, I.A., Yani, M., Ariono, D., Evon, P., and Rigal, L., (2012), In Situ Transesterification of OilContaining Jatropha Curcas Seeds to Produce Biodiesel Fuel, Jurnal Teknik Kimia Indonesia, 11(1), hal. 41-49.

Khang, D.S., Razon, L.F., Madrazo, C.F., and Tan, R.R., (2014), In situ transesterification of coconut oil using mixtures of methanol and tetrahydrofuran, Chemical Engineering Research and Design, 92, pp. $1512-1518$.

Kumar, A., and Sharma, S., (2008), An evaluation of multipurpose oil seed crop for industrial uses (Jatropha curcas L.): a review, Ind. Crops Prod., 28, pp. 1-10 .

Hambali, E., Mujdalipah, S., Tambunan, A.H., Pattiwiri, A.W., dan Hendroko, R., (2007), Teknologi Bioenergi, Agromedia Pustaka, Jakarta.

Okieimen, F.E. and Eromosele, C.O., (1999), Fatty acid composition of seed oil of Khaya Senegalensis, Bioresource Technology, 69, pp. 279-280.

Ong, H.C., Mahlia, T.M.I., Masjuki, H.H., and Nurhasyima, R.S., (2011), Comparison of palm oil, 
Jatropha curcas and Calophyllum inophyllum for biodiesel: A review, Renewable and Sustainable Energy Reviews, 15, pp. 3501-3515.

Radha, K.V. and Manikandan, G., (2011), Novel Production of Biofuels from Neem Oil, World Renewable Energy Congress, Swedia, pp. 471-478.

Shuit, S.H., Lee, K.T., Kamaruddin, A.H., and Yusup, S., (2010), Reactive Extraction and In Situ of Jatropha Curcas L. Seeds for The Production of Biodiesel, Fuel, 89, pp. 527-530.

SNI 04 - 7182 - 2006, Badan Standarisasi Nasional.

Supardan, M.D., Satriana, dan Moulana, R., (2014), Transesterifikasi In Situ Biji Jarak Pagar
Menggunakan Kavitasi Hidrodinamik, Agritech, 34(1), hal. 43-49.

Susilo, B., (2006), Biodiesel : Pemanfaatan Biji Jarak Pagar sebagai Alternatif Bahan Bakar Minyak, Inovasi dan Teknologi, Trubus Agrisarana, Surabaya.

Towaha, J., (2011), Biji Mahoni sebagai Bahan Baku Alternatif Biodiesel, Majalah Semi Populer Tanaman Rempah dan Industri, Pusat Penelitian dan Pengembangan Tanaman Perkebunan, 2(6), hal. 23.

Zeng, J., Wang, X., Zhao, B., Sun, J., and Wang, Y., (2009), Rapid In Situ Transesterification of Sunflower Oil, Ind. Eng. Chem. Res., 48, pp. 850-856. 